\title{
Entrepreneurial Intention: Melalui Kajian Empiris Theory of Planned Behaviour
}

\author{
Oleh: \\ Harini Abrilia Setyawati
}

\begin{abstract}
Abstrak
Jumlah angkatan kerja yang tidak sebanding dengan jumlah lapangan kerja yang ada membuat sebagian orang memilih untuk menjadi wirausaha. Pendidikan tinggi juga mendorong lulusannya untuk kreatif dan inovatif dalam menciptakan lapangan kerja. Mata kuliah kewirausahaan banyak diajarkan di berbagai program studi terutama manajemen.

Penelitian ini bertujuan untuk menguji pengaruh sikap, norma subyektif, dan kontrol perilaku yang dipersepsikan terhadap niat kewirausahaan pada mahasiswa STIE Putra Bangsa. Hasil penelitian menunjukkan bahwa sikap, norma subyektif, dan kontrol perilaku yang dipersepsikan berpengaruh signifikan terhadap niat kewirausahaan.
\end{abstract}

Kata kunci: sikap, norma subyektif, kontrol perilaku yang dipersepsikan dan niat kewirausahaan

\section{Pendahuluan}

Berdasarkan data BPS, diketahui bahwa jumlah angkatan kerja di Indonesia pada sampai dengan bulan Agustus 2012 adalah sebanyak 118, 04 juta orang, dari sejumlah tersebut 110 , 80 juta orang bekerja sedangkan sisanya 7,24 juta orang $(6,14 \%)$ menganggur. Meskipun angka ini menurun dari tahun sebelumnya (6, $56 \%$ ), namun penurunannya tidak begitu signifikan. Kondisi semakin memprihatinkan ketika 6,98 juta orang adalah pengangguran dengan mengantongi ijazah Sarjana dan 2,97 juta orang merupakan lulusan Diploma.

Jumlah lapangan kerja yang tidak sebanding dengan jumlah angkatan kerja ini, mengakibatkan banyaknya pengangguran. Persaingan global semakin mempersempit kesempatan kerja, sebab banyak pekerja yang berasal dari luar negeri. Oleh karena itu perguruan tinggi dengan didukung oleh dikti mengarahkan lulusannya agar menjadi pencipta lapangan pekerjaan bukan hanya menjadi pekerja.

Salah satu upaya yang dilakukan oleh perguruan tinggi adalah dengan memasukan mata kuliah kewirausahaan. STIE Putra bangsa menjadikan kewirausahaan sebagai mata kuliah wajib untuk program studi Manajemen (S1) dan Akuntansi (D3).

Tujuan diberikannya mata kuliah ini adalah supaya mahasiswa mengetahui bagaimana merencanakan dan mengelola sebuah usaha, namun tidak hanya itu saja. Sebenarnya dengan adanya mata kuliah ini diharapkan, mahasiswa semakin berminat untuk menjadi wirausahawan muda yang terdidik.

Theory of Planned Behaviour dengan komponen attitude, subjective norm, perceived control behavior digunakan dalam penelitian ini. Pengembangan dalam penelitian ini yaitu penambahan antecedent 
pendidikan kewirausahaan dan niat berwirausaha sebagai variabel konsekuensi nya.

\section{Kerangka \\ Teoritis \\ Pengembangan \\ Kewirusahaan}

Kewirausahaan adalah proses penciptaan sesuatu yang baru pada nilai menggunakan waktu dan upaya yang diperlukan, menanggung risiko keuangan, fisik, serta risiko sosial yang mengiringi, menerima imbalan moneter yang dihasilkan, serta kepuasan dan kebebasan pribadi. (Hisrich et.al: 2008).

Kewirausahaan juga dapat berarti kemampuan kreatif dan inovatif yang dijadikan dasar, kiat, dan sumber daya untuk mencari peluang menuju sukses. Inti dari kewirausahaan adalah kemampuan untuk menciptakan sesuatu yang baru dan berbeda (create new and different) melalui berpikir kreatif dan bertindak inovatif untuk menciptakan peluang. (Suryana: 2003).

Zimmerer mengartikan kewirausahaan sebagai suatu proses penerapan kreativitas dan inovasi dalam memecahkan persoalan dan menemukan peluang untuk memperbaiki kehidupan (usaha).

Peter Drucker mengatakan bahwa kewirausahaan merupakan kemampuan dalam menciptakan sesuatu baru dan berbeda. Entrepreneurship dan inovasi merupakan hal sentral dalam proses kreatif perekonomian. Inovasi adalah fungsi spesifik dari entrepreneurship, sebagai sebuah cara menciptakan sumberdaya baru yang mendayagunakan sumber daya yang ada untuk menghasilkan kekayaan. Proses kewirausahaan secara tipikal sama dengan proses manajemen strategi (Drucker: 1998).
Secara sederhana kewirausahaan merupakan tindakan mencari peluang dengan menciptakan sesuatu yang baru atau berbeda melalui penambahan nilai pada sumber daya yang dimiliki.

\section{Theory of Planned Behaviour (TPB)}

Theory of Planned Behavior

(TPB) merupakan pengembangan dari Theory of Reasoned Action (TRA) oleh Fishbein dan Ajzen (1975). Dalam model TRA dijelaskan mengenai hubungan perilaku niat (behavioural intention) dengan sikap (attitude) dan norma subyektif (subjective norm). TRA menyatakan bahwa behavioural intention (BI) seseorang bergantung pada attitude (A) dan subjective norm (SN), sehingga dapat digambarkan hubungannya menjadi: $\mathrm{BI}=\mathrm{A}\left(\mathrm{W}_{1}\right)+$ $\mathrm{SN}\left(\mathrm{W}_{2}\right)$. Ajzen memodifikasi TRA dengan menambahkan anteseden intensi yang ke tiga yang disebut perceived behavioral control (PBC).

\section{Niat Berwirausaha (Interpreunerial Intention)}

Ajzen (1988) menjelaskan yang dimaksud dengan intensi yaitu: "intention are assumed to capture to motivational factors that have an compact on a behavior; they are indications of how an effort they are planning to exert, in order to perform the behavior".

Entrepreneurial intention atau niat kewirausahaan dapat diartikan sebagai langkah awal dari suatu proses pendirian sebuah usaha yang umumnya bersifat jangka panjang (Lee \& Wong, 2004). Menurut Krueger (1993), niat kewirausahaan mencerminkan komitmen seseorang untuk memulai usaha baru dan merupakan isu sentral yang perlu diperhatikan dalam memahami proses kewirausahaan pendirian usaha baru. 
Selain itu juga, penjelasan mengenai intensi juga dikemukakan oleh Eagly dan Chaiken (1993) bahwa intensi sebagai konstruk berbeda dengan sikap yang mewakili motivasi seseorang dalam usaha menampilkan suatu tingkah laku.

Dari definisi-definisi yang telah dikemukakan oleh para ahli tersebut dapat disimpulkan bahwa intensi merupakan usaha yang dilakukan seseorang untuk selalu memegang komitmen dalam perencanaan pendirian usaha baru mereka.

\section{Sikap}

Definisi awal sikap dikemukakan oleh Thurstone pada tahun 1993, sikap dilihat sebagai salah satu konsep yang cukup sederhana yaitu jumlah pengaruh yang dimiliki seseorang atas atau menentang suatu objek.

Gordon Allport memberikan definisi tentang sikap yaitu: " An attitude is a mental or neural state of readiness, organized through experience, exerting a directive or dinamyc influence upon the individual's response to all objects and situations with which it is related."

Eagly \& Chaiken mendifinisikan sikap sebagai tendensi yang diekspresikan dengan mengevaluasi gelar istimewa pada beberapa derajat baik dan tidak baik.

Triandis dan ahli lainnya mengkombinasikan tiga jenis tanggapan (pikiran, perasaan dan tindakan) ke dalam model tiga unsur dari sikap (Tripartite Model of Attitude). Dalam skema ini sikap dipandang mengandung tiga komponen yang terkait yaitu kognisi (pengetahuan tentang objek), afeksi (evaluasi positif atau negatif terhadap suatu objek) dan conation (perilaku aktual terhadap suatu objek)

Fishbein \& Ajzen memandang sikap hanya pada satu sisi saja yaitu lebih menekankan pada sisi afektif. Fishbein \& Ajzen (1975) mendefinisikan sikap sebagai berikut : "attitude can be described as a learned predisposition to respon in a consistenly favorable or unfavorable manner with respect to a given project". Dalam penjelasan ini sikap digambarkan sebagai predisposisi (kecenderungan) cara merespon secara konsisten dengan memberikan penilaian suka atau tidak suka terhadap objek. Tiga poin penting menurut mereka mengenai sikap yaitu sikap adalah dipelajari, sikap merupakan predisposisi dari suatu tingkah laku, dan sikap mengandung penilaian baik suka atau tidak suka terhadap suatu objek.

Fishbein \& Ajzen memang menekankan sikap dari segi afektif (penilaian positif atau negatif terhadap objek), namun tidak terlepas dari itu mereka juga berorientasi pada skema triadik. Skema triadik merupakan konstelasi komponen-komponen kognitif, afektif, dan konatif yang saling berinteraksi dalam memahami, merasakan, dan berpeilaku terhadap suatu objek (dalam Azwar, 2002). Hal ini diperkuat dengan pendapat Fishbein \&Ajzen (1975:11-12), yaitu :

"One distinction that has been repeatedly proposed is the age-old trilogy of affect, cognition and conatin. Affect refers to a person's feeling to ward and eveluation of some object, person, issue, or event; cognition denotes his knwledge, opinions, beliefs, and thoughts about the object; and conation refers to his behavioral intentionsand his actions respect to or 
in he presence of the object. Since, when dealing with attitudes, we are concerned with predisposotions to behave rather than behavior it self, it seems desirable to make a distinction between behavioral intention and actual behavioral. This suggest a classification consisting of four broad categories: affect (feelings, evaluation), cognition (opinions, beliefs), conation (behavioral intention), and behavior (observed overt acts)."

Klasifikasi sikap yang diungkap Fishbein \& Ajzen (1975) :

a. Afeksi, mengarah pada perasaan seseorang serta evaluasinya terhadap suatu objek, manusia, pokok persoalan atau peristiwa.

b. Kognisi, nerupakan pengetahuan seseorang, opini-opini, keyakinankeyakinan tentang suatu objek.

c. Konasi, konasi yang dinaksudkan yaitu intensi untuk berperilaku.

d. Perilaku, Fishbein \& Ajzen membedakan antara intensi untuk berperilaku dengan perilaku yang tampak dan dapat diobservasi.

Fishbein dan Ajzen (1975) berpendapat jika ada dua komponen dalam pembentukan sikap yaitu :

Behavioral Belief adalah keyakinankeyakinan yang dimilki seseorang terhadap perilaku dan merupakan keyakinan yang akan mendorong terbentuknya sikap.

Evaluation of behavioral belief merupakan evaluasi positif atau negatif individu terhadap perilaku tertentu berdasarkan keyakinankeyakinan yang dimilikinya.

\section{Norma Subyektif}

Menurut Kreitner \& Kinicki (2001), norma subjektif diartikan sebagai penerimaan tekanan sosial untuk menampilkan sebuah perilaku yang spesifik.

Selanjutnya Fishbein dan Ajzen (1975) menerangkan bahwa "The Subjective norm is the person's perception that most people who are important to him think he should or should not pemrform the behavior in question". Mereka mendefinisikan jika norma subyektif merupakan persepsi individu berhubungan dengan kebanyakan dari orang-orang yang penting bagi dirinya mengaharapkan individu untuk melakukan atau tidak melakukan tingkah laku tertentu, orang - orang yang penting bagi dirinya itu kemudian dijadikan acuan atau patokan untuk mengarahkan tingkah laku.

Norma Subyektif merupakan dasar determinan kedua dari intensi dalam teori planned behavior, norma subyektif pun masih terkait dengan beliefs (keyakinan-keyakinan). Namun belief pada norma subyektif berbeda jenis dengan belief dalam sikap karena belief dalam norma subyektif merupakan representasi persepsi dari significant others (tokoh panutan) baik perorangan maupun berkelompok yang kemudian mempengaruhi individu apakah akan menampilkan perilaku atau tidak.

Norma subyektif menurut Eagly dan Chaiken (1993) maupun Fishbein dan Ajzen (1975) ditentukan oleh dua hal yaitu :

Normative belief, merupakan keyakinan yang berhubungan dengan pendapat tokoh atau orang lain baik perorangan maupun kelompok yang penting dan berpengaruh bagi inidividu yang biasa disebut dengan significant others (tokoh panutan) yang menjadi acuan untuk melakukan atau tidak melakukan perilaku tertentu. Maka 
individu termotivasi untuk melakukan tingkah laku tersebut.

Motivation to comply, yaitu seberapa jauh motivasi individu untuk mengikuti pendapat tokoh panutan tersebut.

\section{Perceived Behavioral Control}

Ajzen

mendefinisikan Perceived Behavioral Control (PBC) sebagai berikut : "this factor refresh to the perceived ease or difficulty peforming the behavior and it assume to reflect past experience as well as anticipates impediment and obstacles", faktor ini menggambarkan persepsi individu mengenai mudah atau tidaknya individu untuk melakukan tingkah laku dan diasumsikan merupakan refleksi dari pengalaman yang telah terjadi sebelumnya serta hambatan-hambatan yang diantisipasi.

Menurut Ajzen (2005), ada dua hal penting terkait dengan theory of planned behavior. Yang pertama adalah asumsi jika PBC memiliki implikasi-implikasi motivasional terhadap intensi. Seseorang yang yakin jika dirinya tidak memiliki sumbersumber maupun tidak memilki kesempatan untuk memunculkan tingkah laku, lebih cenderung tidak akan memiliki intensi yang kuat untuk memunculkan tingkah laku tersebut meskipun ia memiliki attitude toward behavior (sikap terhadap tingkah laku) yang positif dan percaya bahwa orangorang yang penting dan berarti bagi dirinya (significant others) akan setuju ia memunculkan tingkah laku tersebut.

Hal kedua adalah kemungkinan adanya hubungan langsung antara PBC dengan behavior (tingkah laku). Pada beberapa contoh pemunculan tingkah laku tidak hanya tergantung pada motivasi untuk melakukannya tetapi jug adekuat yang mengontrol tingkah laku dalam petanyaan. Dengan demikian PBC dapat memprediksi tujuan bebas tingkah laku intensi, lebih luasnya PBC merefleksikan kontrol langsung dengan derajat keakuratan. Dengan kata lain, PBC dapat mempengaruhi tingkah laku secara tidak langsung, melalui intensi, dan PBC juga dapat digunakan untuk meramalkan tingkah laku secara langsung.

Gambar 1

Kerangka Pemikiran Teoritis

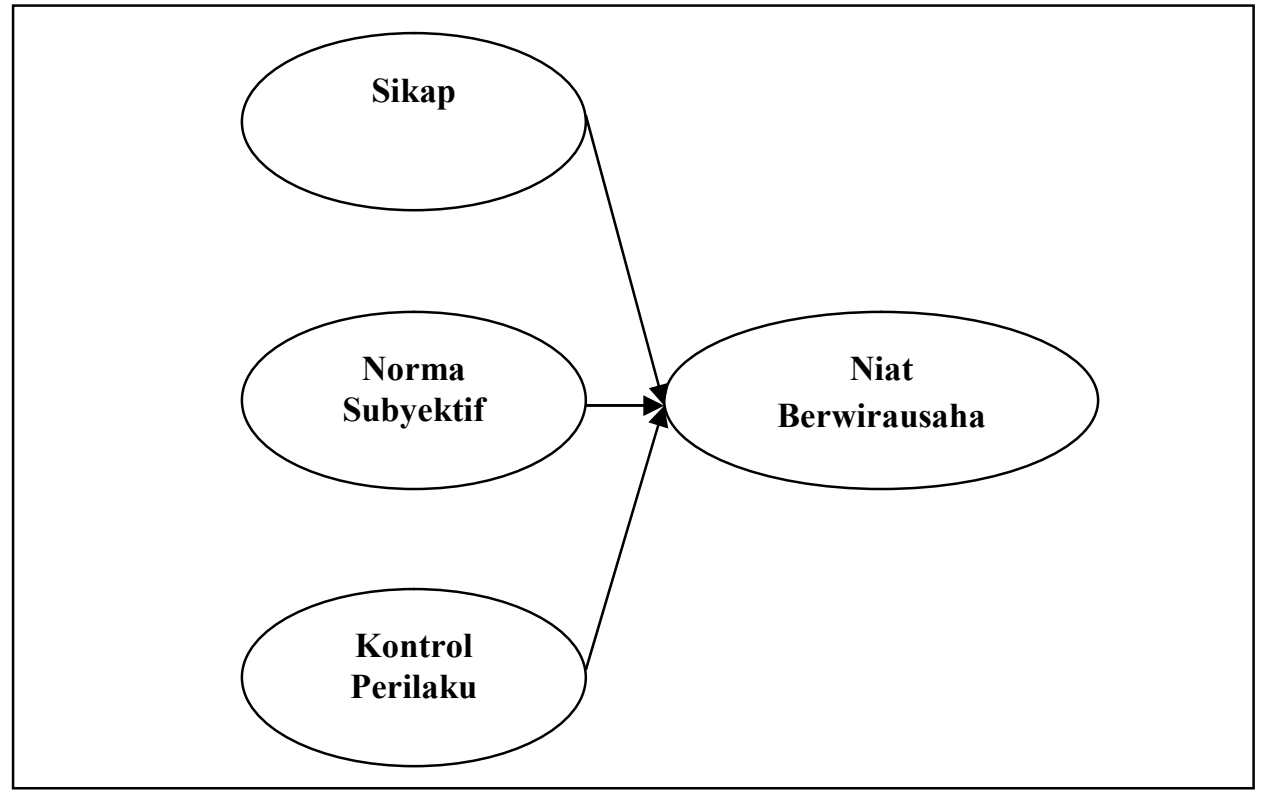




\section{METODE PENELITIAN}

Lokasi penelitian Sekolah Tinggi Ilmu Ekonomi Putra Bangsa. Populasi pada penelitian ini sebanyak 603 mahasiswa. Menggunakan rumus solvin

$\mathrm{n}=$ jumlah sampel

$$
n=\frac{N}{1+N e^{2}}
$$

$\mathrm{N}=$ jumlah seluruh anggota populasi

$\mathrm{e}=$ Error tolerance dengan taraf signifikansi; 0,1

$$
\boldsymbol{n}=\frac{603}{1+603(0,1)^{2}}
$$

Sehingga jumlah sampel yang dibutuhkan dalam penelitian ini sebanyak 86 responden.

Teknik sampling yang digunakan dalam penelitian ini adalah proportional random sampling.

\section{Uji Instrumen}

Untuk menguji validitas kuisioner

\section{Analisis Data}

Analisis data dan Hipotesis dalam penelitian ini akan diuji dengan menggunakan metode SEM dengan alat analisis PLS (Partial Least Square). PLS merupakan analisis SEM menggunakan basis variance. Sebagai alternatif pendekatan, PLS mampu memberikan keunggulan yang mengatasi kelemahan pendekatan SEM berbasis covariance. Pendekatan PLS dianggap powerful karena tidak mendasarkan pada berbagai asumsi. Data dalam analisis PLS tidak harus berditribusi normal (Gozali, 2006). PLS mempunyai kemampuan untuk menangani ukuran sampel yang relatif kecil serta dapat digunakan untuk menganalisis konstruk baik yang bersifat reflektif maupun formatif (Achjari, 2004).

Uji Model Pengukuran atau Outer Model

Outer model (outer relation atau measurement model) mendefinisikan bagaimana setiap blok indikator berhubungan dengan variabel latennya (Ghozali, 2008).

\section{Pengujian Model Struktural (Inner} Model)

Inner model yang kadang disebut juga dengan (inner relation, structural model, dan subtantive theory) menggambarkan hubungan antar variabel laten berdasarkan pada subtantive theory. Model struktural dievaluasi dengan menggunakan $\mathrm{R}$ square untuk konstruk dependen. Interpretasinya sama dengan interpretasi pada regresi (Ghozali, 2008). Perubahan nilai R-square dapat digunakan untuk menilai pengaruh variabel laten independen terhadap variabel laten dependen.

Pengujian hipotesis dapat dilakukan dengan memperhatikan tingkat signifikansi dan koefisien beta. Tingkat signifikansi digunakan untuk melihat signifikan tidaknya hubungan variabel independen dengan variabel dependen, sedangkan koefisien beta digunakan untuk melihat arah hubungan pengaruh variabel independen terhadap variabel dependen. Pengambilan keputusan diterima atau tidaknya hipotesis didasarkan pada 
arah hubungan dan signifikansi dari model yang bersangkutan.

Kriteria penerimaan hipotesisnya adalah menggunakan uji t, dengan melihat apakah nilainilai yang diperoleh koefisien berbeda secara signifikan atau tidak antara $t$ hitung dan $t$ tabel pada tingkat keyakinan $5 \%(\alpha=0,05)$ maka :

Ho diterima jika $t$ hitung $\geq \mathrm{t}$ tabel

Ho ditolak jika $t$ hitung $<\mathrm{t}$ tabelGhozali (2010)

\section{HASIL DAN PEMBAHASAN}

\section{Analisis Data}

\section{Uji Model Pengukuran (Outer Model)}

Outer model digunakan untuk menguji bagaimana setiap indikator atau items berhubungan dengan variabel latennya. Uji model pengukuran tersebut adalah:

\section{Convergent Validity}

Butir pertanyaan (items) dinyatakan valid dan dapat digunakan untuk perhitungan dalam menganalisis hasil apabila skor komponen lebih besar dari nilai kriteria minimum yaitu 0,500 (Ghozali, 2008). Berikut merupakan gambar dan hasil perhitungan convergent validity :

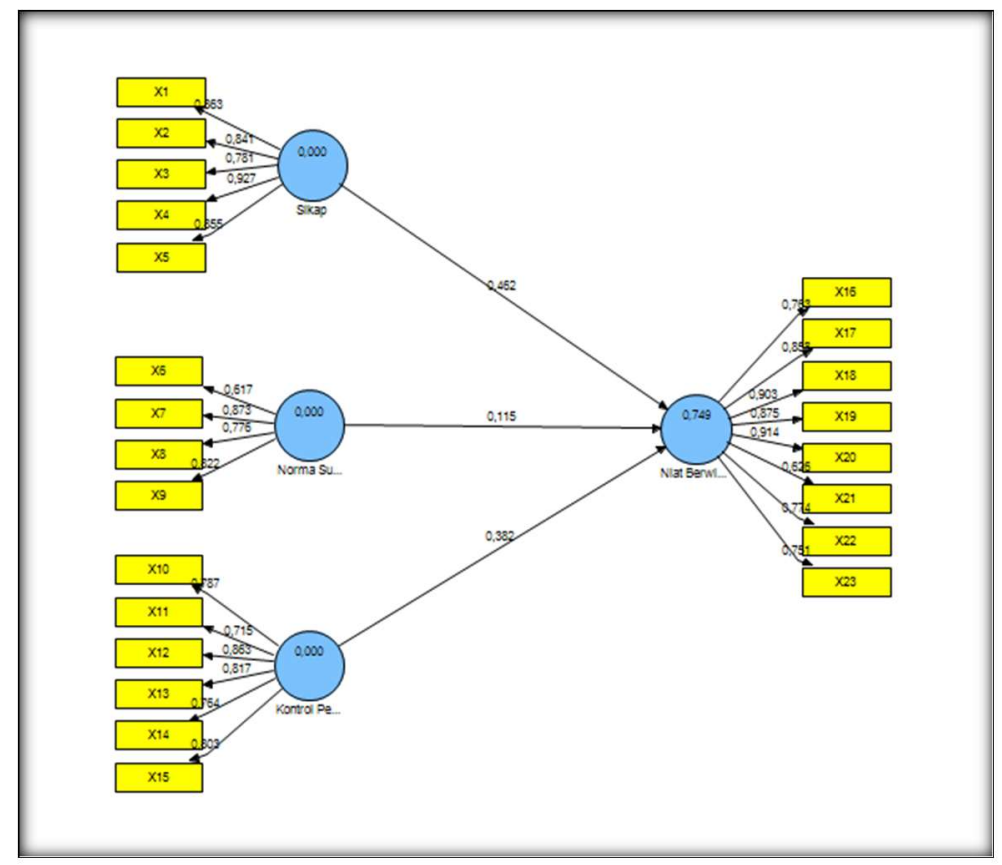

Gambar 4.1 Convergent Validity

Berikut tabel penjelasan gambar hasil perhitungan convergent validity :

Tabel 4.2

Skor Convergent Validity

\begin{tabular}{l|ccc}
\hline Pertanyaan & $\begin{array}{c}\text { Skor } \\
\text { Komponen }\end{array}$ & $\begin{array}{c}\text { Kriteria } \\
\text { Minimum }\end{array}$ & Hasil \\
\hline \hline X1 $\leftarrow$ Sikap & 0,86304 & 0,5 & valid \\
X2 $\leftarrow$ Sikap & 0,841442 & 0,5 & valid \\
X3 Sikap & 0,781137 & 0,5 & valid \\
X4 Sikap & 0,92691 & 0,5 & valid \\
X5 Sikap & 0,855026 & 0,5 & valid
\end{tabular}




\begin{tabular}{|c|c|c|c|}
\hline X6 $\leftarrow$ Norma Subyektif & 0,617485 & 0,5 & valid \\
\hline X7 $\leftarrow$ Norma Subyektif & 0,873037 & 0,5 & valid \\
\hline $\mathbf{X 8} \leftarrow$ Norma Subyektif & 0,776395 & 0,5 & valid \\
\hline X9 $\leftarrow$ Norma Subyektif & 0,822044 & 0,5 & valid \\
\hline $\mathrm{X10} \leftarrow \underset{\text { Kontrol Perilaku yang }}{\text { Dipersepsikan }}$ & 0,787111 & 0,5 & valid \\
\hline $\mathrm{X} 11 \leftarrow \underset{\text { Kontrol Perilaku yang }}{\text { Dipersepsikan }}$ & 0,714924 & 0,5 & valid \\
\hline $\mathrm{X} 12 \leftarrow \underset{\text { Kontrol Perilaku yang }}{\text { Dipersepsikan }}$ & 0,863196 & 0,5 & valid \\
\hline $\mathrm{X} 13 \leftarrow \underset{\text { Kontrol Perilaku yang }}{\text { Dipersepsikan }}$ & 0,816832 & 0,5 & valid \\
\hline $\mathrm{X} 14 \leftarrow \underset{\substack{\text { Kontrol Perilaku yang } \\
\text { Dipersepsikan }}}{ }$ & 0,763975 & 0,5 & valid \\
\hline X15 $\leftarrow \begin{array}{l}\text { Kontrol Perilaku yang } \\
\text { Dipersepsikan }\end{array}$ & 0,802522 & 0,5 & valid \\
\hline $\mathrm{X} 16 \leftarrow$ Niat Berwirausaha & 0,762595 & 0,5 & valid \\
\hline $\mathrm{X} 17 \leftarrow$ Niat Berwirausaha & 0,858299 & 0,5 & valid \\
\hline $\mathrm{X} 18 \leftarrow$ Niat Berwirausaha & 0,902904 & 0,5 & valid \\
\hline $\mathrm{X} 19 \leftarrow$ Niat Berwirausaha & 0,875437 & 0,5 & valid \\
\hline $\mathrm{X} 20 \leftarrow$ Niat Berwirausaha & 0,913606 & 0,5 & valid \\
\hline $\mathrm{X} 21 \leftarrow$ Niat Berwirausaha & 0,625804 & 0,5 & valid \\
\hline $\mathrm{X} 22 \leftarrow$ Niat Berwirausaha & 0,773765 & 0,5 & valid \\
\hline $\mathrm{X} 23 \leftarrow$ Niat Berwirausaha & 0,751432 & 0,5 & valid \\
\hline
\end{tabular}

Sumber: Data Diolah, 2013

Pada tabel 4.2 terlihat bahwa semua skor sudah berada di atas 0,5 sehingga skor sudah valid.

\section{Discriminant Validity}

Discriminant validity dari model pengukuran dinilai berdasarkan cross loading pengukuran dengan konstruk (variabel). Jika korelasi konstruk dengan item pengukuran lebih besar daripada ukuran konstruk lainnya, maka hal tersebut menunjukkan bahwa konstruk laten (indikator/items) memprediksi ukuran pada blok mereka lebih baik daripada ukuran pada blok lainnya (Ghozali, 2008).

Tabel 4.3

Cross Loadings

\begin{tabular}{c|cccc}
\hline & Sikap & $\begin{array}{c}\text { Norma } \\
\text { Subyektif }\end{array}$ & $\begin{array}{c}\text { Kontrol } \\
\text { Perilaku yang } \\
\text { Dipersepsikan }\end{array}$ & $\begin{array}{c}\text { Niat } \\
\text { Berwirausaha }\end{array}$ \\
\hline \hline X1 & $\mathbf{0 , 8 6 3 0 4}$ & 0,42771 & 0,57544 & 0,64872 \\
X2 & $\mathbf{0 , 8 4 1 4 4}$ & 0,41328 & 0,56720 & 0,60074 \\
X3 & $\mathbf{0 , 7 8 1 1 4}$ & 0,62584 & 0,67100 & 0,74935 \\
X4 & $\mathbf{0 , 9 2 6 9 1}$ & 0,52390 & 0,68535 & 0,70768 \\
X5 & $\mathbf{0 , 8 5 5 0 3}$ & 0,50581 & 0,58948 & 0,71973 \\
X6 & 0,20410 & $\mathbf{0 , 6 1 7 4 9}$ & 0,43847 & 0,38746 \\
X7 & 0,59468 & $\mathbf{0 , 8 7 3 0 4}$ & 0,62334 & 0,65569 \\
\hline
\end{tabular}




\begin{tabular}{c|llll}
$\mathbf{X 8}$ & 0,46667 & $\mathbf{0 , 7 7 6 4 0}$ & 0,41555 & 0,39625 \\
$\mathbf{X 9}$ & 0,50564 & $\mathbf{0 , 8 2 2 0 4}$ & 0,44591 & 0,45032 \\
$\mathbf{X 1 0}$ & 0,46620 & 0,52640 & $\mathbf{0 , 7 8 7 1 1}$ & 0,54586 \\
$\mathbf{X 1 1}$ & 0,60618 & 0,63827 & $\mathbf{0 , 7 1 4 9 2}$ & 0,58456 \\
$\mathbf{X 1 2}$ & 0,62588 & 0,53560 & $\mathbf{0 , 8 6 3 2 0}$ & 0,72163 \\
$\mathbf{X 1 3}$ & 0,51583 & 0,40091 & $\mathbf{0 , 8 1 6 8 3}$ & 0,58479 \\
$\mathbf{X 1 4}$ & 0,53613 & 0,49944 & $\mathbf{0 , 7 6 3 9 8}$ & 0,60534 \\
$\mathbf{X 1 5}$ & 0,68142 & 0,42777 & $\mathbf{0 , 8 0 2 5 2}$ & 0,69057 \\
$\mathbf{X 1 6}$ & 0,58380 & 0,52756 & 0,62468 & $\mathbf{0 , 7 6 2 6 0}$ \\
$\mathbf{X 1 7}$ & 0,67973 & 0,49636 & 0,53429 & $\mathbf{0 , 8 5 8 3 0}$ \\
$\mathbf{X 1 8}$ & 0,71699 & 0,65028 & 0,68350 & $\mathbf{0 , 9 0 2 9 0}$ \\
$\mathbf{X 1 9}$ & 0,72508 & 0,56378 & 0,60289 & $\mathbf{0 , 8 7 5 4 4}$ \\
$\mathbf{X 2 0}$ & 0,78510 & 0,56034 & 0,75935 & $\mathbf{0 , 9 1 3 6 1}$ \\
$\mathbf{X 2 1}$ & 0,49252 & 0,40127 & 0,73603 & $\mathbf{0 , 6 2 5 8 0}$ \\
$\mathbf{X 2 2}$ & 0,60061 & 0,40852 & 0,60613 & $\mathbf{0 , 7 7 3 7 7}$ \\
$\mathbf{X 2 3}$ & 0,62892 & 0,45821 & 0,58011 & $\mathbf{0 , 7 5 1 4 3}$ \\
\hline Smber
\end{tabular}

Sumber: Data Diolah, 2013

Dilihat dari tabel diatas, terlihat bahwa konstruk laten memprediksi indikator pada blok mereka lebih baik dibandingkan dengan indikator di blok lainnya.

Tabel 4.4

AVE

\begin{tabular}{c|ccc}
\hline Variabel & AVE & $\begin{array}{c}\text { Akar Kuadrat } \\
\text { AVE }\end{array}$ & Keterangan \\
\hline \hline $\begin{array}{c}\text { Kontrol Perilaku } \\
\text { yang Dipersepsikan }\end{array}$ & 0,62845 & 0,79275 & Diterima \\
Niat Berwirausaha & 0,66119 & 0,81314 & Diterima \\
Norma Subyektif & 0,60551 & 0,77814 & Diterima \\
Sikap & 0,73065 & 0,85478 & Diterima \\
\hline diterima $>0,50$
\end{tabular}

Sumber: Data Diolah, 2013

Nilai AVE direkomendasikan harus lebih besar dari 0,5 (Chin, dalam Ghozali, 2008). Dilihat dari tabel diatas, terlihat bahwa AVE seluruh konstruk lebih tinggi dari 0,5.

Tabel 4.5

Latent Variable Correlations

\begin{tabular}{c|cccc}
\hline & $\begin{array}{c}\text { Kontrol } \\
\text { Perilaku yang } \\
\text { Dipersepsikan }\end{array}$ & $\begin{array}{c}\text { Niat } \\
\text { Berwirausaha }\end{array}$ & $\begin{array}{c}\text { Norma } \\
\text { Subyektif }\end{array}$ & Sikap \\
\hline \hline $\begin{array}{c}\text { Kontrol Perilaku yang } \\
\text { Dipersepsikan }\end{array}$ & 1 & & & \\
Niat Berwirausaha & 0,791189 & 1 & & \\
Norma Subyektif & 0,633809 & 0,630977 & 1 & 1 \\
Sikap & 0,727613 & 0,808361 & 0,591883 & 1 \\
\hline
\end{tabular}

Sumber: Data Diolah, 2013

Nilai square root of average variance exracted (akar kuadrat AVE) dibandingkan untuk setiap konstruk dengan konstruk lainnya dalam model. Jika nilai akar kuadrat AVE setiap konstruk lebih besar daripada nilai korelasi antara konstruk satu dengan konstruk lainnya Jurnal Fokus Bisnis, Volume 14, No 02, bulan Desember 2015 
dalam model, maka dikatakan memiliki nilai discriminant validity yang baik (Fornell dan Larcker, 1981 dalam Ghozali, 2008).

Selain itu perbandingan akar kuadrat AVE secara keseluruhan lebih tinggi dibanding dengan korelasi antar konstruk. Jadi semua konstruk dalam model yang diestimasi telah memenuhi kriteria discriminant validity.

\section{Uji Reliabilitas}

Reliabilitas instrumen ditentukan dari nilai composite reliability. Composite reliability merupakan ukuran reliabilitas dari blok indikator dalam mengukur konstruknya (internal consistence). Besarnya composite reliability harus lebih besar dari 0,60 (Chin, dalam Ghozali, 2008).

\section{Tabel 4.6}

Composite Reliability

\begin{tabular}{c|cc}
\hline Variabel & $\begin{array}{c}\text { Composite } \\
\text { Reliability }\end{array}$ & Keterangan \\
\hline \hline Kontrol Perilaku & 0,910029 & Diterima \\
yang Dipersepsikan & 0,939079 & Diterima \\
Niat Berwirausaha & 0,858091 & Diterima \\
Norma Subyektif & 0,931144 & Diterima \\
Sikap &
\end{tabular}

diterima $>0,60$

Sumber: Data Diolah, 2013

Hasil output dari composite reliability konstruk di atas 0,60 , sehingga dapat dilanjutkan tahap berikutnya.

\section{Pengujian Model Struktural (Inner Model)}

Model struktural dievaluasi dengan menggunakan R-square untuk konstruk dependen. Interpretasinya sama dengan interpretasi pada regresi (Ghozali, 2008). Perubahan nilai R-square dapat digunakan untuk menilai pengaruh variabel laten independen terhadap variabel laten dependen.

\section{Tabel 4.7}

\begin{tabular}{c|c}
\multicolumn{2}{c}{ R Square } \\
\hline & R Square \\
\hline \hline Niat Berwirausaha & 0,748522 \\
Kontrol Perilaku & \\
yang Dipersepsikan & \\
Norma Subyektif & \\
Sikap & \\
\hline Sumber: Data Diolah, 2013
\end{tabular}

Sumber: Data Diolah, 2013

Tabel diatas menunjukkan bahwa : Variabel niat berwirausaha dijelaskan oleh Sikap, Norma Subyektif dan Kontrol Perilaku yang Dipersepsikan sebesar 74, 85\%

\section{Pengujian Hipotesis}

Pengujian hipotesis dapat dilakukan dengan memperhatikan tingkat signifikansi dan koefisien path antar variabel laten. Untuk menguji hipotesis yang diajukan, dilakukan analisis statistik dengan memasukkan variabel yang diuji secara bersama-sama. Pengambilan keputusan didasarkan pada arah hubungan dan signifikansi dari model yang bersangkutan. Berikut adalah hasil output perhitungan Partial Least Square menggunakan software SmartPLS 2.0. 
Tabel 4.8

Path Coefficients (Mean, STDEV, T-Values)

\begin{tabular}{c|ccccc}
\hline & $\begin{array}{c}\text { Original } \\
\text { Sample } \\
(\mathbf{O})\end{array}$ & $\begin{array}{c}\text { Sample } \\
\text { Mean } \\
(\mathbf{M})\end{array}$ & $\begin{array}{c}\text { Standard } \\
\text { Deviation } \\
\text { (STDEV) }\end{array}$ & $\begin{array}{c}\text { Standard } \\
\text { Error } \\
\text { (STERR) }\end{array}$ & $\begin{array}{c}\text { T Statistics } \\
\text { (|O/STERR|) }\end{array}$ \\
\hline \hline $\begin{array}{c}\text { Kontrol Perilaku yang } \\
\text { Dipersepsikan - Niat } \\
\text { Berwirausaha }\end{array}$ & 0,381575 & 0,385952 & 0,079597 & 0,079597 & 4,793823 \\
$\begin{array}{c}\text { Norma Subyektif -> } \\
\text { Niat Berwirausaha } \\
\text { Sikap -> Niat } \\
\text { Berwirausaha }\end{array}$ & 0,115452 & 0,10902 & 0,075028 & 0,075028 & 1,538785 \\
\hline
\end{tabular}

Sumber: Data Diolah, Lampiran

Berdasarkan tabel diatas, nilai original sample menunjukkan hubungan yang positif atau negatif antar variabel. Sedangkan $t$ statistik digunakan untuk melihat signifikansi hubungan antar variabel. Hubungan dianggap signifikan jika $t$ statistik lebih besar dibanding dengan $\mathrm{T}$ tabel. Dengan menggunakan tingkat keyakinan sebesar $95 \%(\alpha=0,05)$ dan degree of freedom $(\mathrm{df})=(\mathrm{n}-\mathrm{k}-1)$ diperoleh nilai $\mathrm{t}$ tabel sebesar 2,01669

Dengan demikian dapat disimpulkan bahwa :

1. Hipotesis pertama

Berdasarkan tabel 4.8, menunjukkan bahwa nilai t statistik sebesar 5,788448 > 2,01669 (t tabel), hal ini berarti hubungan antara Sikap terhadap Niat Berwirausaha adalah signifikan dengan arah positif (berbanding lurus) ditunjukan dengan koefisien positif. Sehingga H1 yang menyatakan bahwa Sikap berpengaruh positif terhadap Niat Berwirausaha diterima.

2. Hipotesis kedua

Berdasarkan tabel 4.8, menunjukkan bahwa nilai t statistik sebesar 1,538785 < 2,01669 (t tabel), hal ini berarti hubungan antara Norma Subyektif terhadap Niat Berwirausaha adalah signifikan dengan arah positif (berbanding lurus) ditunjukan dengan koefisien positif. Sehingga H2 yang menyatakan bahwa Norma Subyektif berpengaruh positif terhadap Niat Berwirausaha ditolak.

3. Hipotesis ketiga

Berdasarkan tabel 4.8, menunjukkan bahwa nilai t statistik sebesar 4,793823 > 2,01669 ( $\mathrm{t}$ tabel), hal ini berarti hubungan antara Kontrol Perilaku yang Dipersepsikan terhadap Niat Berwirausaha adalah signifikan dengan arah positif (berbanding lurus) ditunjukan dengan koefisien positif. Sehingga H3 yang menyatakan bahwa Kontrol Perilaku yang Dipersepsikan berpengaruh positif terhadap Niat Berwirausaha diterima.

\section{DAFTAR PUSTAKA}

Ajzen, I. 1991. The Theory of Planned Behavior. Organizational Behavior \& Human Decision Processes, 50(2): 179-211.

Ajzen, I. 2005. Theory of planned behaviour: Frequently asked questions. Retrieved March, 30, 2010, http://www.people.umass.edu/aizen/faq.html. 
Ajzen, I., \& Fishbein, M. 1980. Understanding attitudes and predicting social behavior. Englewood Cliffs, NJ: Prentice-Hall.

Busenitz, L. W., West Iii, G. P., Shepherd, D., Nelson, T., Chandler, G. N., \& Zacharakis, A. 2003. Entrepreneurship Research in Emergence: Past Trends and Future Directions. Journal of Management, 29(3): 285-308.

Campbell, C. R., \& Martinko, M. J. 1998. An Integrative Attributional Perspective of Empowerment and Learned Helplessness: A Multimethod Field Study. Journal of Management, 24(2): 173-200.

Conner, M., \& Armitage, C. J. 1998. Extending the Theory of Planned Behavior: A Review and Avenues for Further Research. Journal of Applied Social Psychology, 28(15): 1429-1464.

Cruz, N. M., Escudero, A. I. R., Barahona, J. H., \& Leitao, F. S. 2009. The Effect of Entrepreneurship Education Programmes on Satisfaction with Innovation Behaviour and Performance. Journal of European Industrial Training, 33(3): 198-214.

Hisrich et.al. 2008. Kewirausahaan. Jakarta: Salemba Empat.

Kasmir. 2007. Kewirausahaan. Jakarta: PT RajaGrafindo Persada

Kermit, W. 2008. Entrepreneurial Intention Research: Implications for entrepreneurship education. Journal of Entrepreneurship Education, Annual 2008.

Kristiansen, S., \& Indarti, N. 2004. Entrepreneurial intention among Indonesian and Norwegian students. Journal of Enterprising Culture, 12(1): 55-78.

Shapero, A., \& Sokol, L. 1982. The social dimensions of entrepreneurship. In C. Kent, Sexton, D., Vesper, K. (Ed.), Encyclopedia of Entrepreneurship: 72-90. Englewood Cliffs, New Jersey: Prentice-Hall, Inc.

Shapero. A, \& Sokol, L. 1982. The social dimensions of entrepreneurship. In C. Kent, Sexton, D., Vesper, K. (Ed.), Encyclopedia of Entrepreneurship. Englewood Cliffs, New Jersey: Prentice-Hall, Inc.

Shepperd, B. H., Hartwick, J., \& Warshaw, P. R. 1988. The Theory of Reasoned Action: A Meta-Analysis of Past Research with Recommendations for Modifications and Future Research. Journal of Consumer Research, 15(3): 325-325.

Setiadi, Nugroho J. 2003. Perilaku Konsumen. Jakarta: Prenada Media

Suryana. 2003. Kewirausahaan: Pedoman Praktis, Kiat dan Proses Menuju Sukses. Jakarta: Salemba Empat.

Suryani, Ninik. 2008. Perilaku Konsumen: Implikasi pada Strategi Pemasaran. Yogyakarta: Graha Ilmu.

Zimmerer, et.al. 2008. Kewirausahaan dan Manajemen Usaha Kecil. Jakarta: Salemba Empat. 